\title{
An assessment of the quality of liquid effluents from opaque beer-brewing plants in Bulawayo, Zimbabwe
}

\author{
DIO Ikhu-Omoregbe ${ }^{1 *}$, PK Kuipa ${ }^{2}$ and $\mathrm{M} \mathrm{Hove}^{2}$ \\ ${ }^{1}$ School of Chemical Engineering, University of KwaZulu-Natal, Durban, South Africa. \\ ${ }^{2}$ Department of Chemical Engineering, National University of Science and Technology, Bulawayo, Zimbabwe
}

\begin{abstract}
The quality of liquid effluents from two opaque sorghum beer-brewing plants in Bulawayo, Zimbabwe were studied by analysing snap and composite samples collected manually from the plants' effluent discharge points over a period of six months. Both plants generate effluents that could negatively impact on the municipal treatment system if no efforts are made to significantly reduce their pollution load in terms of both quality and quantity. The results from both plants for the main pollution indicators showed high values of chemical oxygen demand (COD) (in excess of $30000 \mathrm{mg} / \ell$ in some instances), biological oxygen demand (BOD) and suspended solids (SS), indicating high organic load. Analysis of BOD values indicates that the effluents are biologically degradable. No significant heavy metals were found in the effluents, as these are food-processing plants. The effluent treatment plants in both plants were not only inadequate but also poorly operated thereby rendering them ineffective in reducing the pollution loads of the effluents. Simple good housekeeping and operational practices and well as design modifications are suggested to reduce the pollution load of the effluents.
\end{abstract}

Keywords: industrial effluents, opaque beer-brewery, pollution load, quality, quantity

\section{Introduction}

In recent years, a number of environmental pollution incidents have led to a renewed drive to monitor and control the quality and quantity of liquid effluents being discharged especially by industries into the municipal treatment systems and natural watercourses in Zimbabwe. Recent examples of contamination of water-bodies include eutrophication of Lake Chivero due the presence of inorganic nutrients such as nitrogen and phosphorus compounds in excessive amounts, most of which originated from industrial activities (Marshal, 1997) and the case of the contamination of Ncema Dam with cyanide washed from a gold mine as a result of heavy rainfall (The Chronicle, 2000). The result of this drive is that a number of industries and some municipal authorities have been fined by the Zimbabwe National Water Authority (ZINWA) for discharging effluents whose qualities were not compliant with its standards for the discharge of such effluents into natural watercourses.

The discharge of poor quality effluents especially by industries into the municipal wastewater treatment works has the effect of reducing the performance of these treatment facilities over time due to hydraulic overloading and corrosion of the sewer pipe system (Nyoni, 1999; Norplan, Stewart Scott Zimbabwe and CNM and Partners, 2001). This problem has been worsened by the fact that industries within the jurisdiction of the city of Bulawayo were permitted to dispose of effluents into the municipal sewers, provided the quality of such effluents was within the regulatory standards as set out in the City Council By-Laws of 1980 (Bulawayo By-Laws, 1980). Consequently, most industrial establishments within the city do not have effluent pretreatment plants and on sites where they exist, their performance is not up to standard. The

* To whom all correspondence should be addressed.

要+2731 260-3376; fax:+2731 260-1118

e-mail: ikhuomoregbe@ukzn.ac.za

Received 16 January 2004; accepted in revised form 25 October 2004. situation has further been compounded by the council's inability to effectively monitor compliance with and implement its by-laws (Ikhu-Omoregbe et al., 2001). However, as a result of the New Act of 1998 and the guidelines thereof most urban councils, including Bulawayo, in Zimbabwe are in the process of adopting the "polluter pays principle" in managing industrial pollution. Here the producer of any pollution would be made to pay the full cost of treatment to reduce the pollution loads to levels, which will not cause environmental damage or loss of beneficial use to others together with the cost of monitoring and management. Thus a factory that generates substantial effluents must take steps to reduce its pollution load before ultimate discharge into the municipal sewerage system.

It is well known that in most developing countries, industries dispose of their effluents without adequate characterisation, quantification and pretreatment due to economic and technological constraints (Sweeney, 1995). The main objective of this study was to characterise and quantify the liquid effluent pollution load from these two plants thereby generating reliable data for planning and cleaner production practices for both the industries and the local authority. The paper also discusses the current liquid effluent disposal/treatment practices and offers suggestions on possible remediation. Furthermore, it assesses the level of compliance to the local legislative guidelines for effluent disposal.

\section{Effluent generation and treatment in the two breweries}

The two breweries studied in this paper produce African traditional sorghum malt beer. The plants will be referred to as Plant A and Plant $B$ respectively. Plant A has a production capacity of $100 \times 10^{6} \ell$ of beer per year while Plant B has a capacity of $23 \times 10^{6} \ell$ of beer per year. Both breweries use municipal water for their process water.

Plant A carries out its milling and malt preparation on the same premises as the brewing process while for Plant B these two initial stages in sorghum beer-brewing are done outside of the plant 
premises. Besides this difference all the other processing stages are the same in both plants. The two brewery plants have effluent treatment units that were designed to remove SS through flocculation, coagulation and settling using lime. However, in both plants these units were not operating optimally due to operational and design limitations. The effluent treatment plants were designed to handle smaller volumes than those being generated as evidenced by regular overflows from the equalisation and sedimentation tanks especially at Plant B.

The sources of effluents in both plants are similar and these include general cleaning and sanitation, spills and poor hygiene practices, bottle washing using caustic soda and returns from customers due to product becoming stale and solids from strainers. After the effluents have been "treated", Plant A discharges its wastewater into the municipal sewerage system while Plant B discharges its waste content into a nearby stream or uses the effluent for irrigation purposes which produces an offensive odour as it is ineffectively treated. This was due to the fact that during our study, we observed that the activated charcoal in the absorber column was neither regenerated nor replaced leading to poor performance of this absorber column.

\section{Methods and materials}

\section{Wastewater sampling}

The sampling protocol was divided into two phases. The objectives of this two-phased sampling program were to establish trends and process variations (Phase 1), then estimate weekly and monthly means and deviations using results from both phases and to confirm the results from Phase 1. The first phase was a high-frequency (intensive) sampling period where three to five $500 \mathrm{~m} \ell$ snap samples were collected during each visit to the plant. The samples were collected every $2 \mathrm{~h}$ but at times the sampling was process-timed to pick out maximum and minimum pollution producing activities. About 200 m $\ell$ was taken from each snap sample and mixed to produce one composite sample for that day.

Phase 1 sampling was done for about two months at a rate of one industry visit after every $8 \mathrm{~d}$. This was done so that benefits of both random (different days of the week) and systematic (every 8 d) sampling could be realised. The samples from Plant A were collected at the points of entering the treatment unit and of discharge into the municipal sewer system. For Plant B, sampling was also at the entry to the treatment unit and at the point of discharge into the irrigation system. The second phase of the monitoring exercise involved taking snap samples randomly over a period of four months.

\section{Wastewater characterisation}

Each of the snap and composite samples was analysed for parameters such as temperature, $\mathrm{pH}$, hardness, turbidity, TDS, SS, chlorides, sulphates and nitrates which were thought to be significant. The metals included iron, copper, lead and zinc, while the aggregate organic constituents included COD and BOD. Samples were analysed using appropriate classical and instrumental methods (Standard Methods, 1998, Skong and Leary, 1992). TDS, conductivity, and temperature were measured using a conductivity meter (Hach Model SensIon 5) and the $\mathrm{pH}$ was measured using a $\mathrm{pH}$ meter (Hach Model SensIon 1). The BOD measurement was done using respirometric methods (according to the Hach Incubator BODTREK Model 206). The procedures adapted for the ions and metals were such that the Hach DR/2010 Spectrophotometer could be used.
Samples were collected and analysed within $24 \mathrm{~h}$ with necessary preservation techniques according to the Zimbabwe Water Authority (1999). However, parameters such as temperature, conductivity and $\mathrm{pH}$ were determined on the spot. For samples where analyte concentration was out of range for the analytical method, necessary dilution with demineralised water was done according to the Hach DR/2010 Spectrophotometer Procedures Manual. A portable openchannel flow meter was used to measure effluent flow rates (Miltronic OCM III).

\section{Analytical quality assurance}

For all the methods that required the use of the spectrophotometer, both reagent blanks and sample blanks were used. Standard solutions were prepared for the analysis of COD and BOD. Before any measurement could be done, instruments were calibrated using standard solutions. The sample bottles were made from plastic materials cleaned thoroughly using a detergent, $1: 1 \mathrm{HCl}$, triplerinsed with distilled water and a final triple rinse with the sample as suggested by Fatoki and Mathabatha (2001). The data obtained were used to calculate means, ranges, standard deviations, pollution loads and BOD rate constant.

\section{Results and discussion}

\section{Plant A: Effluent characteristics}

The results for this plant are shown in Figs. 1 to 12, for both sampling phases and Table 1 shows the statistically derived results. The results indicate that the effluents discharged from Plant A do not comply with the requirements for the discharge of such effluents as stated in the Bulawayo City Council effluent discharge standards. A comparison of the parameters on the inlet side ("in" on the charts) of the effluent treatment unit and the outlet side ("out” on the charts) indicates that the treatment unit apparently increases the pollutant concentration, instead of reducing it. The vales for COD and SS appear higher in the outlet stream than in the inlet steam to the treatment plant. The high standard deviations obtained for the COD (Table 1) show that there is great variability (between and within days) in the nature of the effluent and therefore would need equalisation before any treatment.

The values of the main parameters COD and SS showed a slight decrease in the second phase compared to the values obtained in the first phase. However, the values were not low enough to fall within the statutory requirement set out by the City Council. The COD for Phase 1 ranged from $8060 \mathrm{mg} / \ell$ to $60400 \mathrm{mg} / \ell$ while the values for Phase II were between $380 \mathrm{mg} / \ell$ and $13810 \mathrm{mg} / \ell$. The average CODvalues were $18734 \mathrm{mg} / \ell$ and $28722 \mathrm{mg} / \ell$ for the inlet and outlet points respectively for Phase I sampling, and $6662 \mathrm{mg} / \ell$ and 7550 $\mathrm{mg} / \ell$ for the inlet and outlet points respectively for Phase II. This trend suggests that spot sampling of the effluent from this plant could lead to a wrong estimation of the effluent concentrations. The standard deviations for the same monitoring period also show similar trends. The decrease in COD values between the phase samplings was as a result of the plant, based on our suggestions and observations, adopting an improved housekeeping practice. Continuous discharges of effluent of these qualities would have resulted in serious consequences including possible factory closure by the municipal authorities.

The levels of COD obtained in the first monitoring phase in particular were observed to be relatively higher than the average of $17000 \mathrm{mg} / \ell$ reported in the literature (Dupont et al., 2000; WRC, 1989). The differences could be due to the differing operational 


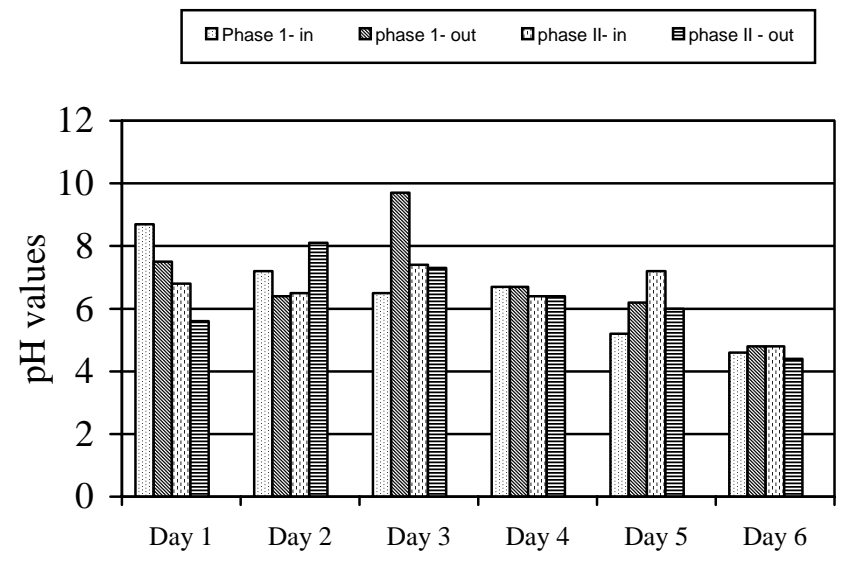

Figure 1

pH levels for both phases for Plant $A$

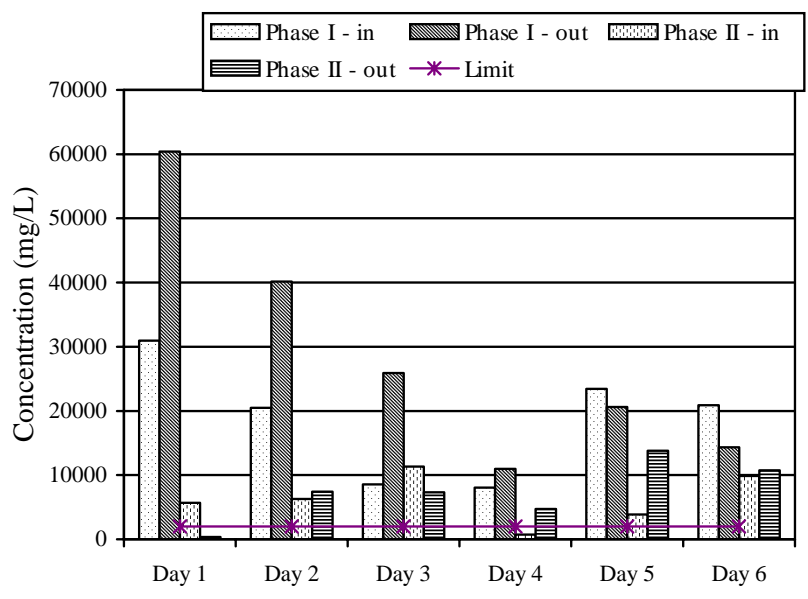

Figure 2

Concentrations of COD ( $\mathrm{mg} / \mathrm{\ell})$ on different days for both Phases I and II for Plant $A$

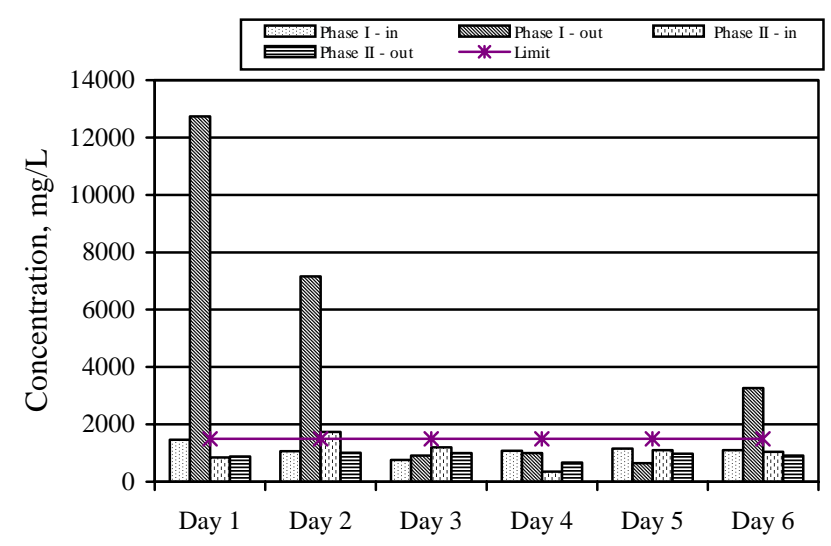

Figure 3

Concentrations of BOD ( $\mathrm{mg} / \mathrm{\ell})$ on different days for both Phases I and II for Plant $A$

procedures especially in the effluent management programs in the individual breweries monitored in the respective studies. They also indicate the level of operational efficiencies and capabilities existing in the different plants.

Another interesting observation is that the inlet pollution parameter values were observed to be lower than the outlet figures

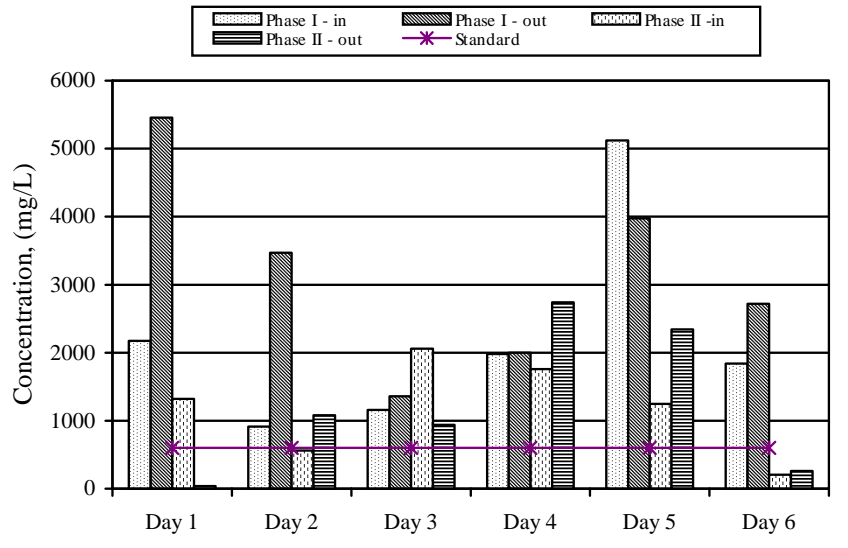

Figure 4

Concentrations of (SS) on different days for both Phases I and II for Plant A

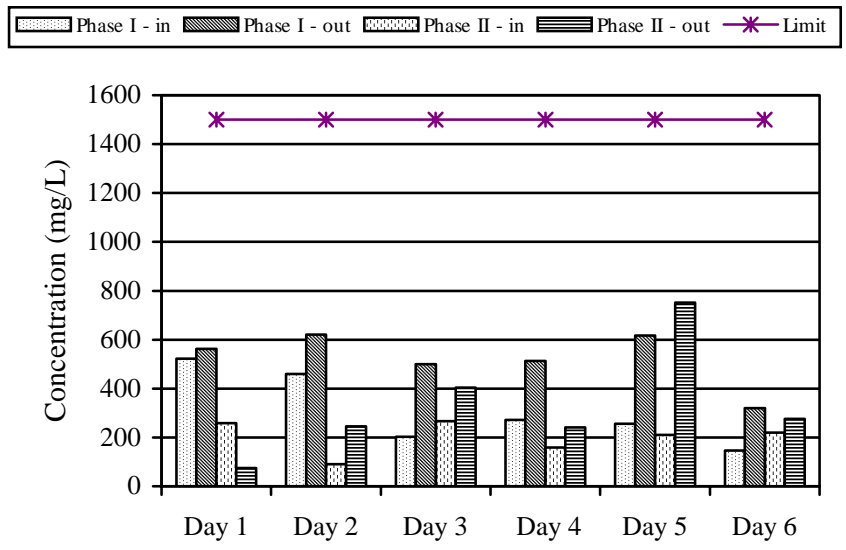

Figure 5

Concentrations of total dissolved solids (TDS), ( $m g / \ell$ ) on different days for both Phases I and II for Plant $A$

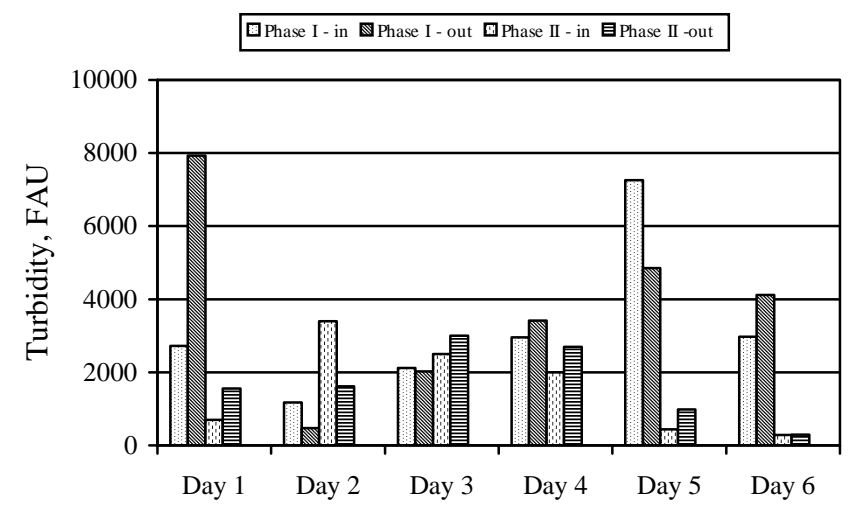

Figure 6

Turbidity (FAU) of the effluents on different days for both Phases I and II for Plant $A$

suggesting that there is an increase in the organic pollution concentration as the effluents pass through the treatment plant. This can be explained by the fact that the lime used in $\mathrm{pH}$ correction could have also acted as a coagulant (Stephenson and Blackburn, 1998) thereby improving the settling properties of the solids. It was observed that the overflow system for the treatment plant was 

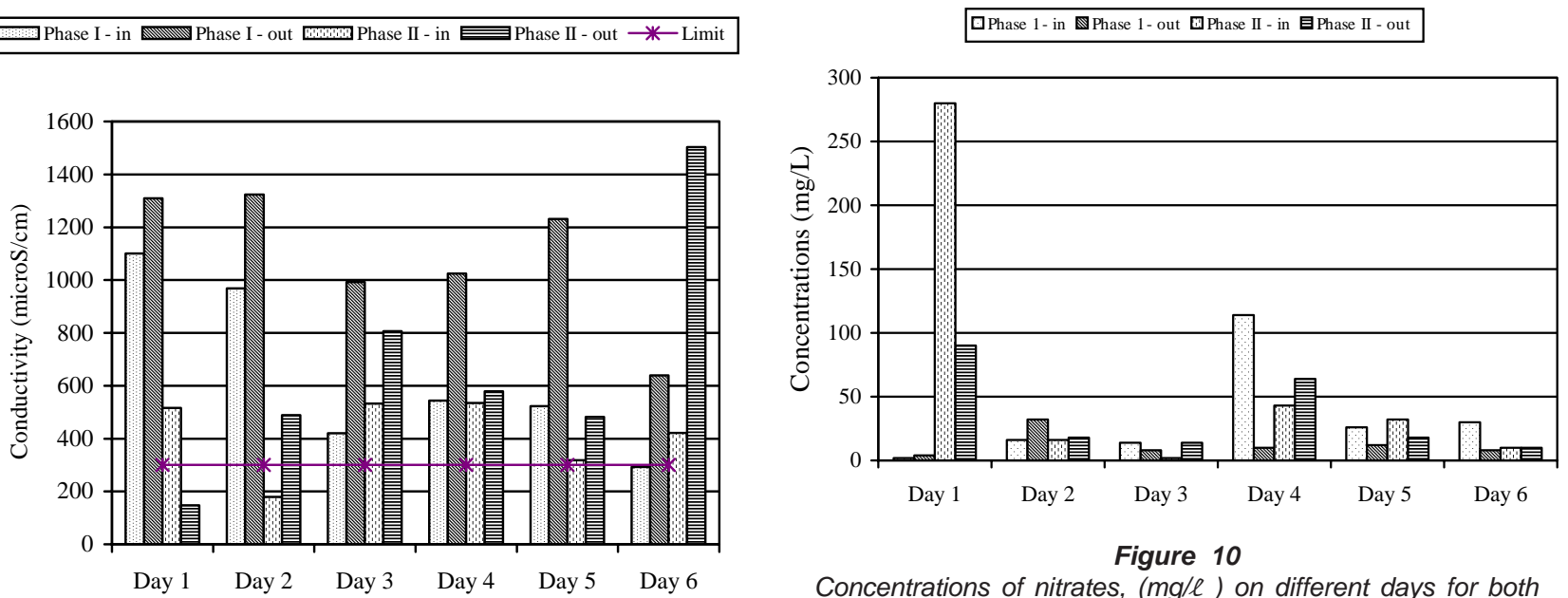

Figure 7

Conductivity, $(\mu \mathrm{S} / \mathrm{cm})$ of the effluents on different days for both Phases I and II for Plant A

Figure 10

Concentrations of nitrates, ( $\mathrm{mg} / \mathrm{l}$ ) on different days for both Phases I and II for Plant A

$\square$ Lead - in 0 Phase 1 - in $\mathbb{8}$ Phase 1 - out 0 Phase II - in $\mathbf{O}$ Phase II - out

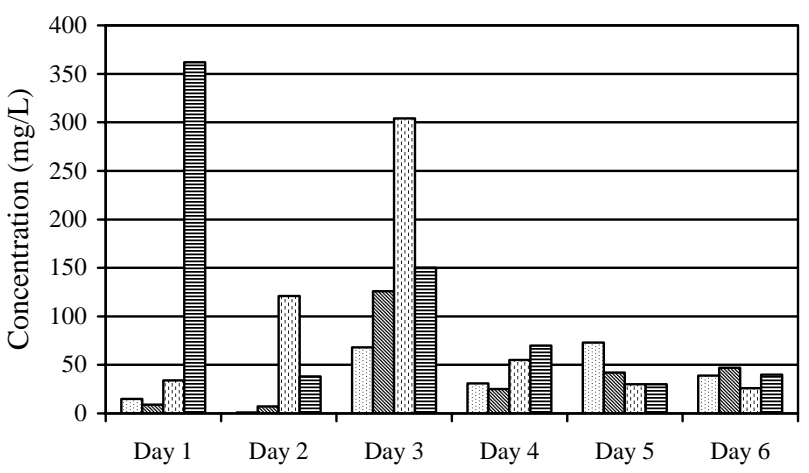

Figure 8

Concentrations of phosphates of the effluents on different days for both Phases I and II for Plant A
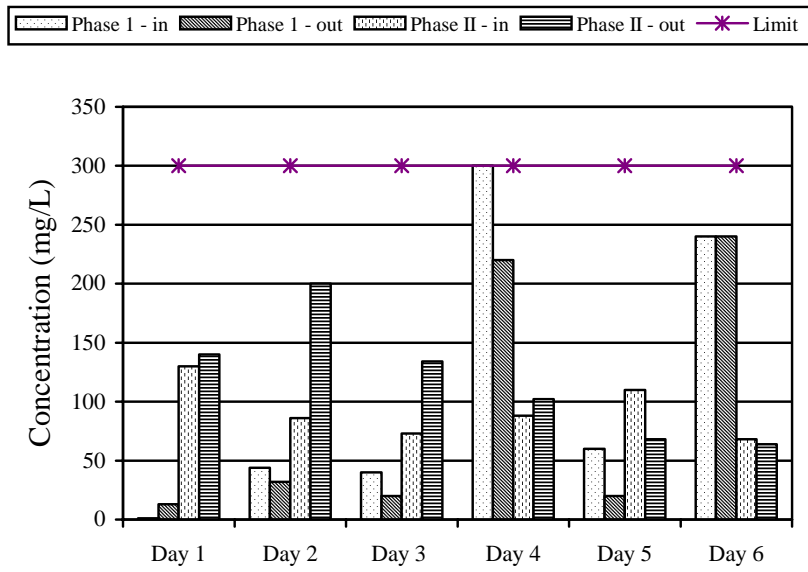

Figure 9

Concentrations of sulphates $(\mathrm{mg} / \ell)$ on different days for both Phases I and II for Plant $A$

faulty and discharge was through an underflow pump and pipe system so the effluent discharged was more concentrated in terms of solids content. This increased solids content is thought to account

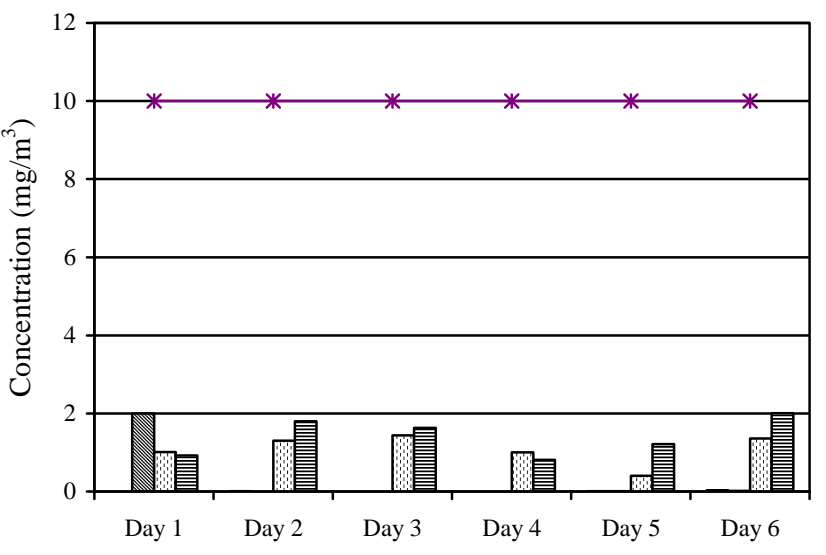

Figure11

Concentrations of lead and iron, $\mu \mathrm{g} / \ell$ on different days for Plant A, Phase II

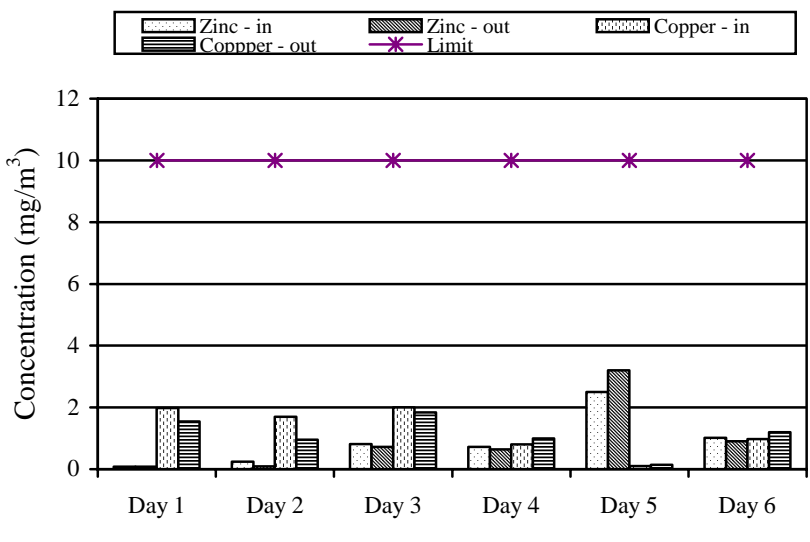

Figure 12

Concentrations of zinc and copper $\mu \mathrm{g} / \ell$ on different days for Plant A, Phase II

for the increase in the levels of other parameters such as electrical conductivity, SS and COD. The $\mathrm{pH}$ values obtained were found to be within the range of reported values for breweries in general (Dupont et al., 2000). 


\begin{tabular}{|c|c|c|c|c|c|c|}
\hline \multicolumn{7}{|c|}{$\begin{array}{c}\text { TABLE1 } \\
\text { Statistical summary of data for Plant A }\end{array}$} \\
\hline \multirow[t]{2}{*}{ Parameter } & \multicolumn{3}{|c|}{ Phase I } & \multicolumn{3}{|c|}{ Phase II } \\
\hline & Range & Average & $\begin{array}{l}\text { Standard } \\
\text { deviation }\end{array}$ & Range & Average & $\begin{array}{l}\text { Standard } \\
\text { deviation }\end{array}$ \\
\hline $\mathrm{pH}$ & $\begin{array}{c}3.6-10.3 \\
4.5-9.7\end{array}$ & $\begin{array}{l}6.5 \\
7.0\end{array}$ & $\begin{array}{l} \pm 1.3 \\
\pm 1.5\end{array}$ & $\begin{array}{l}4.8-7.4 \\
4.4-8.1\end{array}$ & $\begin{array}{l}6.5 \\
6.3\end{array}$ & $\begin{array}{l} \pm 0.8 \\
\pm 0.1\end{array}$ \\
\hline $\begin{array}{l}\text { Temperature, } \\
{ }^{\circ} \mathrm{C}\end{array}$ & $\begin{array}{l}23-31 \\
23-36\end{array}$ & $\begin{array}{l}26 \\
28\end{array}$ & $\begin{array}{l} \pm 1 \\
\pm 2\end{array}$ & $\begin{array}{l}20-26 \\
20-26\end{array}$ & $\begin{array}{l}23 \\
22\end{array}$ & $\begin{array}{l} \pm 2.0 \\
\pm 2.0\end{array}$ \\
\hline BOD & $\begin{array}{c}760-1465 \\
820-12732\end{array}$ & $\begin{array}{l}1105 \\
5338\end{array}$ & $\begin{array}{l} \pm 225 \\
\pm 4544\end{array}$ & $\begin{array}{l}350-1740 \\
670-1010\end{array}$ & $\begin{array}{c}1048 \\
909\end{array}$ & $\begin{array}{l} \pm 508 \\
\pm 144\end{array}$ \\
\hline Phosphate & $\begin{array}{l}1.3-73 \\
7-126\end{array}$ & $\begin{array}{l}38 \\
43\end{array}$ & $\begin{array}{l} \pm 26 \\
\pm 40\end{array}$ & $\begin{array}{c}26-30 \\
430-362\end{array}$ & $\begin{array}{c}90 \\
103\end{array}$ & $\begin{array}{l} \pm 86 \\
\pm 104\end{array}$ \\
\hline Sulphate & $\begin{array}{c}1-300 \\
13-240\end{array}$ & $\begin{array}{c}114 \\
91\end{array}$ & $\begin{array}{l} \pm 113 \\
\pm 99\end{array}$ & $\begin{array}{l}68-130 \\
64-200\end{array}$ & $\begin{array}{c}61 \\
111\end{array}$ & $\begin{array}{l} \pm 19 \\
\pm 46\end{array}$ \\
\hline Nitrate & $\begin{array}{c}2-114 \\
4-32\end{array}$ & $\begin{array}{l}34 \\
12\end{array}$ & $\begin{array}{l} \pm 37 \\
\pm 9\end{array}$ & $\begin{array}{l}2-280 \\
10-90\end{array}$ & $\begin{array}{l}60 \\
38\end{array}$ & $\begin{array}{l} \pm 85 \\
\pm 27\end{array}$ \\
\hline COD & $\begin{array}{c}8060-30950 \\
10980-60400\end{array}$ & $\begin{array}{l}18734 \\
28722\end{array}$ & $\begin{array}{l} \pm 8127 \\
\pm 16982\end{array}$ & $\begin{array}{l}730-11320 \\
380-13810\end{array}$ & $\begin{array}{l}6662 \\
7550\end{array}$ & $\begin{array}{l} \pm 3140 \\
\pm 3729\end{array}$ \\
\hline SS & $\begin{array}{c}915-5120 \\
1360-5456\end{array}$ & $\begin{array}{l}2199 \\
3164\end{array}$ & $\begin{array}{l} \pm 1381 \\
\pm 1342\end{array}$ & $\begin{array}{c}204-2060 \\
40-2740\end{array}$ & $\begin{array}{c}996 \\
1156\end{array}$ & $\begin{array}{l} \pm 652 \\
\pm 950\end{array}$ \\
\hline $\begin{array}{l}\text { Turbidity } \\
\text { (FAU) }\end{array}$ & $\begin{array}{l}1180-7260 \\
2020-7930\end{array}$ & $\begin{array}{l}3204 \\
4553\end{array}$ & $\begin{array}{l} \pm 1918 \\
\pm 1806\end{array}$ & $\begin{array}{l}289-3400 \\
298-3000\end{array}$ & $\begin{array}{l}1523 \\
1623\end{array}$ & $\begin{array}{c} \pm 1081 \\
\pm 968\end{array}$ \\
\hline TDS & $\begin{array}{l}120-608 \\
256-659\end{array}$ & $\begin{array}{l}310 \\
522\end{array}$ & $\begin{array}{l} \pm 135 \\
\pm 102\end{array}$ & $\begin{array}{l}90-267 \\
74-752\end{array}$ & $\begin{array}{l}196 \\
304\end{array}$ & $\begin{array}{l} \pm 67 \\
\pm 192\end{array}$ \\
\hline Conductivity & $\begin{array}{l}293-1100 \\
639-1324\end{array}$ & $\begin{array}{c}640 \\
1087\end{array}$ & $\begin{array}{l} \pm 292 \\
\pm 238\end{array}$ & $\begin{array}{c}179-535 \\
147-1503\end{array}$ & $\begin{array}{l}393 \\
608\end{array}$ & $\begin{array}{l} \pm 135 \\
\pm 384\end{array}$ \\
\hline $\begin{aligned} \text { NOTE: All para } \\
\text { - First } \mathrm{r} \\
\text { - Secon }\end{aligned}$ & $\begin{array}{l}\text { neters are in } \mathrm{mg} / \ell \\
\mathrm{w} \text { data refer to ra } \\
\text { row data refers }\end{array}$ & $\begin{array}{l}\text { less other } \\
\text { intreated e } \\
\text { eated efflu }\end{array}$ & $\begin{array}{l}\text { e stated } \\
\text { lent } \\
\text { discharged }\end{array}$ & m treatmen & & \\
\hline
\end{tabular}

Heavy metal concentrations found in the effluents were at trace levels, therefore within limits set by the municipal authorities. The presence of iron and other metals could be due to corrosion of water pipes and other metallic plant structures. Copper will start to dissolve in water at $\mathrm{pH}$ below 6.5 and at hardness levels at less than $60 \mathrm{mg} / \ell$ (Gray, 1999).

The BOD test can be used to determine the treatability of effluents by biological treatment processes. It has been reported that for bio-treatability of an effluent by aerobic oxidation, the COD: BOD ratio must be between 1.5 and 2.5 (Dupont et al., 2000; Kilani, 1993). This supports the observation that the BOD test is an aerobic digestion model which would give low values for cellulosic materials, which are easier to stabilise under anaerobic conditions. The BOD values obtained in this monitoring exercise were low when compared to the COD values giving a COD: BOD ratio for Plant A of 5.57. This is in contrast to reported lower COD: BOD ratios for brewery effluents (Kilani, 1993; Strydom et al., 1993). This high COD: BOD ratio is thought to be due the lower level of operational efficiencies and poorer housekeeping operations in Plant A.

Analysis of the BOD curves show that the effluents are biodegradable. The COD: BOD ratio of the effluents suggests that the effluents will be amenable to anaerobic digestion or trickling filters (Hosang et al., 2001). Another parameter that can be used to assess the kinetics of aerobic digestion of effluents is the degradation rate constant, $\mathrm{K}_{\mathrm{L}}$, which is related to the organic substrate concentration S and the rate of oxidation (Gray, 1999; Mihelcic, 1999). A Thomas slope plot is used to find the value of $\mathrm{K}_{\mathrm{L}}$ from BOD data. The value of $\mathrm{K}_{\mathrm{L}}$ for Plant A was found to be $0.3 / \mathrm{d}$. Reported values of $\mathrm{K}_{\mathrm{L}}$ for brewery effluents lie between 0.15 and 0.2891 (Kilani, 1993; Strydom et al., 1993).

The Thomas graphical method (Gray, 1999) for determining $\mathrm{K}_{\mathrm{L}}$ is based on the equation: 


$$
\left(\frac{t}{y}\right)^{1 / 3}=\left(2.3 K_{L} L\right)^{-1 / 3}+\frac{K_{L}^{2 / 3}}{3.43 L^{1 / 3}} . t
$$

where:

$\mathrm{y}=$ BOD exerted in time $\mathrm{t}$

$K_{L}=$ Reaction rate constant

$L=$ Ultimate (carbonaceous) BOD

Plotting a graph of $(t / y)^{1 / 3}$ as a function of time t gives a straight line and its gradient is used to calculate $\mathrm{K}_{\mathrm{L}}$.

The data shown in Table 2 were calculated from the flow volumes and the minimum, average and maximum constituent concentrations. From the pollution load data the major part of the organic loading of significance is in the form of SS. Thus optimisation and improvement of the solids removal would help to reduce the COD levels in the effluent. This would in turn bring the COD: BOD ratio to within 1.5 and 2.5. This can be achieved by incorporating screens before the equalisation tanks in the present pretreatment set-up. Standardisation of the cleaning processes through integrated water management techniques can also help to reduce the amount of water used as well as the use of CIP systems and water jets. Equalisation of the effluents before treatment with lime could reduce the quantity and cost of lime being used as the high alkaline sanitisation effluent would then neutralise the acidic first wash.

\section{Plant B: Effluent characteristics}

In this plant, samples were collected at the inlet ("in" in the charts) to the treatment plant and at the irrigation tap ("out" in the charts) for the outlet from the treatment plant. Figures 13 to 24 show the characteristics of the effluents for both monitoring phases and Table 3 , the statistically derived results. Generally, the pollutant levels are lower in this plant when compared to corresponding values from Plant A. However, the effluents from this plant do not conform to the regulatory standards in terms of the main pollution indicators such as COD and SS. The trends in the values did not show significant differences in both phases over the six months monitoring period. The outlet concentration levels remained higher than the inlet concentrations suggesting again treatment plant operational inefficiencies. The variability in the pollution indicators remained high indicated by the large standard deviations from the mean.

The average COD concentration values were observed to be $5880 \mathrm{mg} / \ell$ for the outlet stream and $4920 \mathrm{mg} / \ell$ for the inlet stream into the treatment plant during the Phase I sampling period. For

DPhase 1 - in $\mathbb{Q}$ Phase 1 - out DPhase II - in GPhase II - out

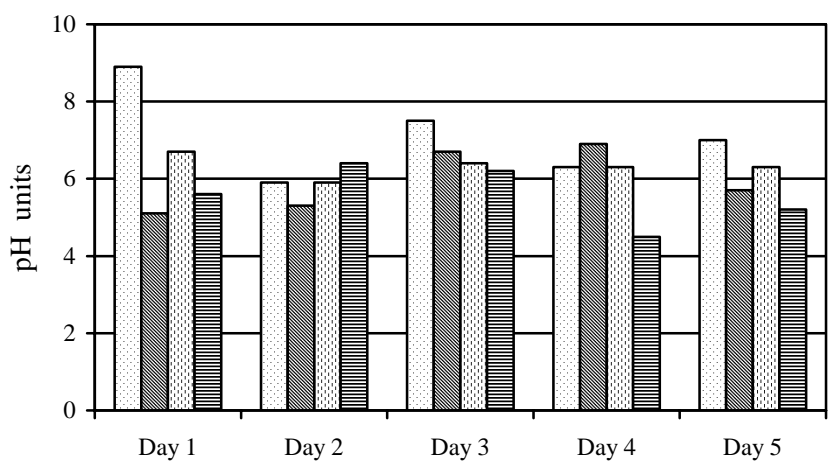

Figure 13

$\mathrm{pH}$ levels for both phases for Plant $B$

\begin{tabular}{|l|c|c|}
\hline \multicolumn{3}{|c|}{ TABLE2 } \\
Pollution load, Plant A \\
\hline Parameter & Average & Range \\
\hline Volume, $\left(\mathrm{m}^{3} / \mathrm{d}\right)$ & 1795 & $948-2665$ \\
COD, $(\mathrm{kg} / \mathrm{d})$ & 22793 & $692-82482$ \\
BOD, $(\mathrm{kg} / \mathrm{d})$ & 1114 & $1075-1153$ \\
$\mathrm{SS},(\mathrm{kg} / \mathrm{d})$ & 2868 & $193-13645$ \\
TDS $(\mathrm{kg} / \mathrm{d})$ & 454 & $85-1391$ \\
\hline
\end{tabular}
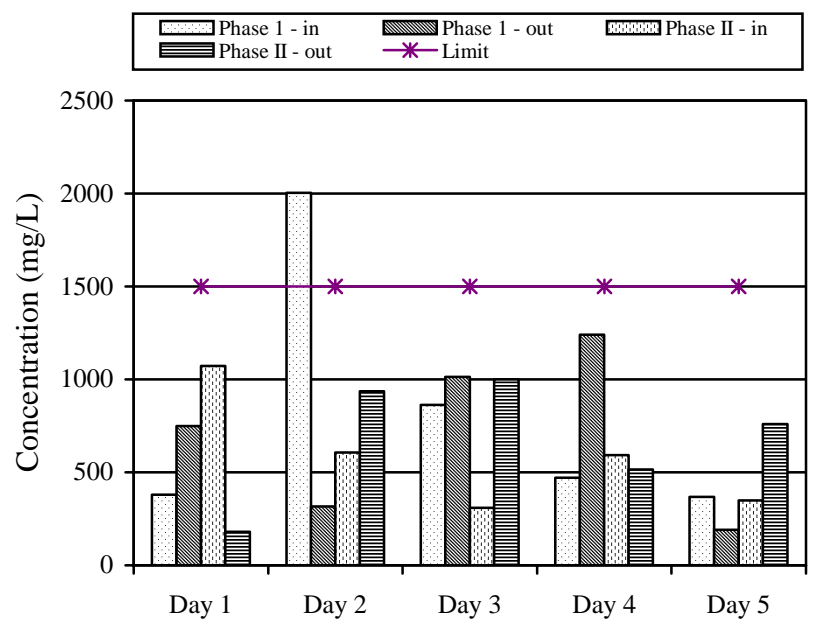

Figure 14

Concentrations of BOD, mg/l of effluents in and out of the treatment plant on different days for Plant B, Phases I and II

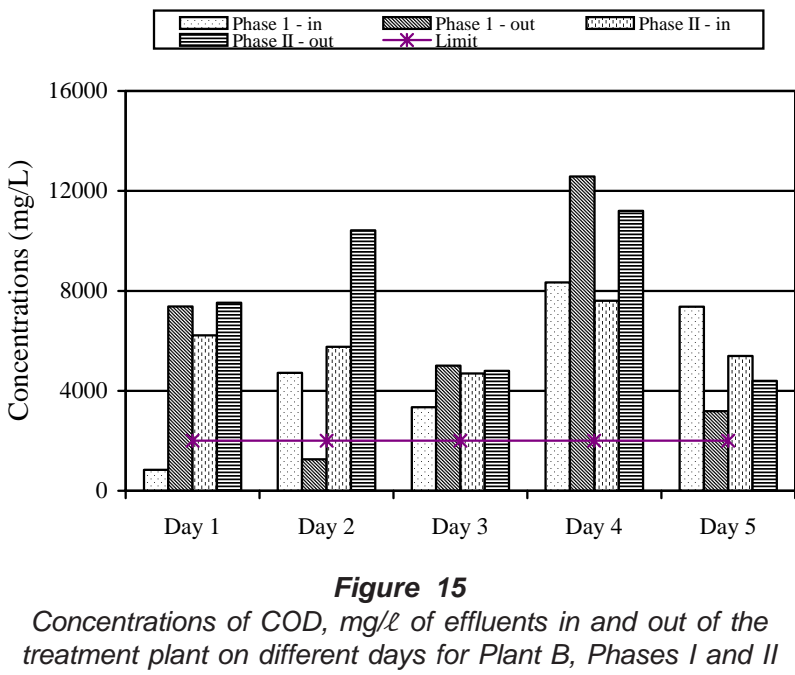

Phase II the corresponding mean COD values were 4391 and 6650 $\mathrm{mg} / \ell$ respectively. These values are comparable to reported values for some brewery plants (Kilani, 1991; Dupont et al., 2000). The SS averages were $864 \mathrm{mg} / \ell$ at the inlet point and $1836 \mathrm{mg} / \ell$ at the outlet point from the treatment plant for Phase I sampling. The corresponding SS concentrations obtained in Phase II, were $614 \mathrm{mg} / \ell$ and $952 \mathrm{mg} / \ell$ for the inlet and outlet points respectively. Once again, similar to the situation in Plant A, it appears that instead of reducing the pollutant concentration, the treatment plant is 

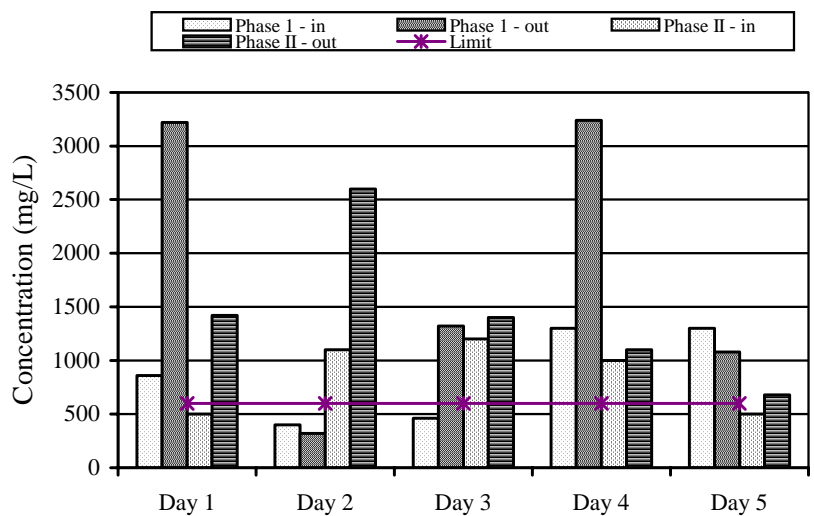

Figure 16

Concentrations of SS, mg/l of effluents in and out of the treatment plant on different days for Plant B, Phases I and II.

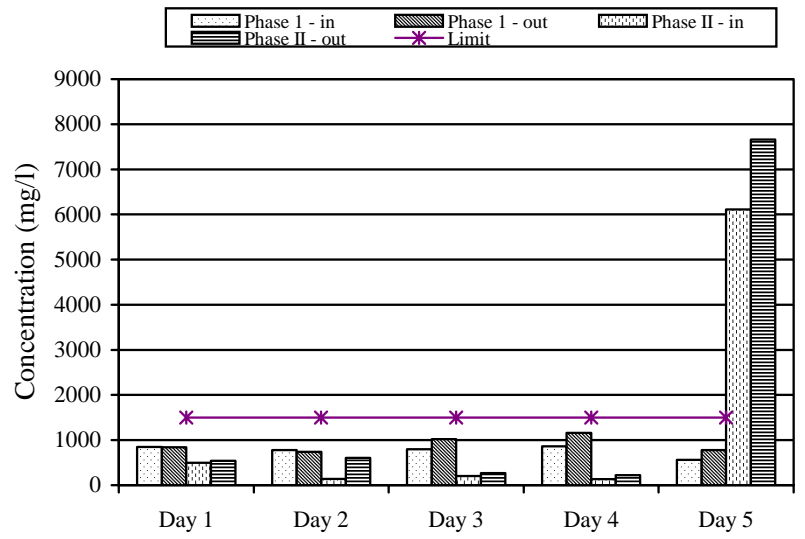

Figure 17

Concentrations of Total dissolved solids (TDS), mg/ $\ell$ of effluents in and out of the treatment plant on different days for Plant B, Phases I and II

$$
\square \text { Phase } 1 \text { - in } \square \text { Phase } 1 \text {-out } \square \text { Phase II - in 目 Phase II - out }
$$

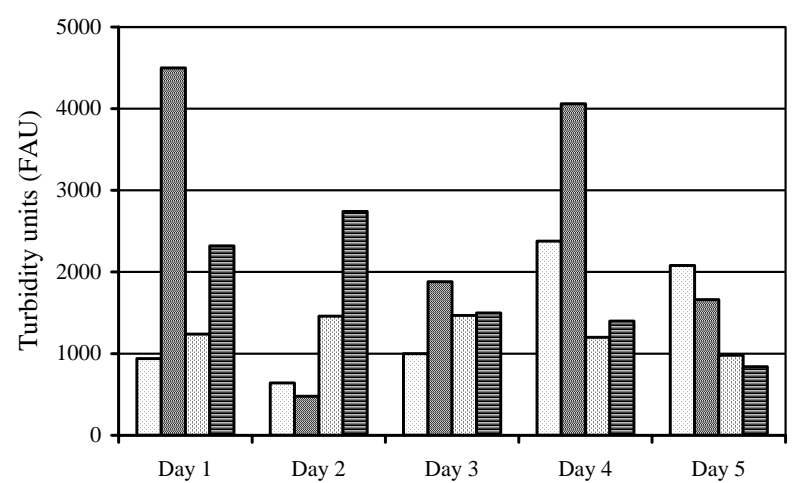

Figure 18

Turbidity (FAU) of effluents in and out of the treatment plant on different days for Plant B, Phases I and II

apparently increasing the level of the pollutants. This anomaly is again due to poor operational practices at the treatment plant especially in terms of solids removal from the equalisation and holding tanks. It was observed that there was no effective separation

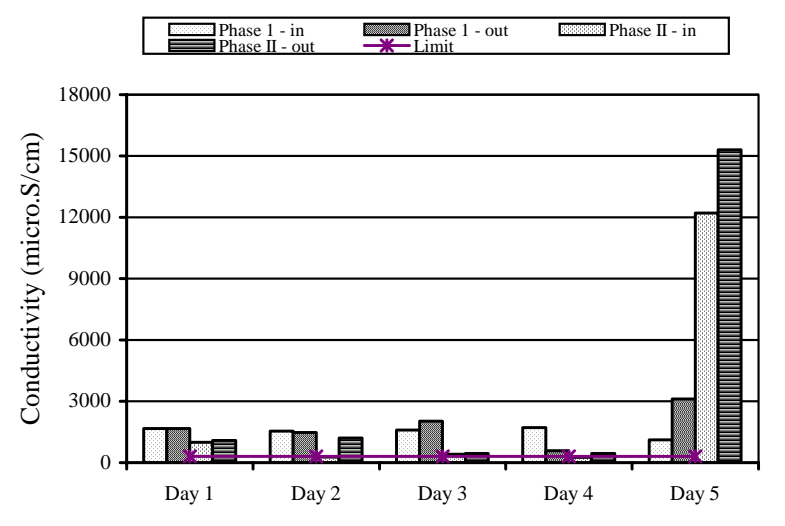

Figure 19

Conductivity, $(\mu \mathrm{S} / \mathrm{cm})$ of the effluents in and out of the treatment plant on different days for Plant B, Phases I and II

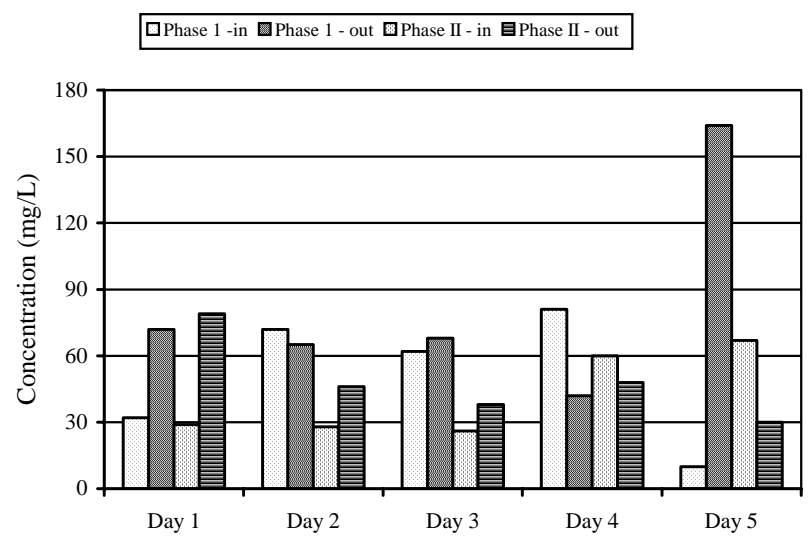

Figure 20

Concentrations of phosphates, mg/l of effluents in and out of the treatment plant on different days for Plant B, Phases I and II

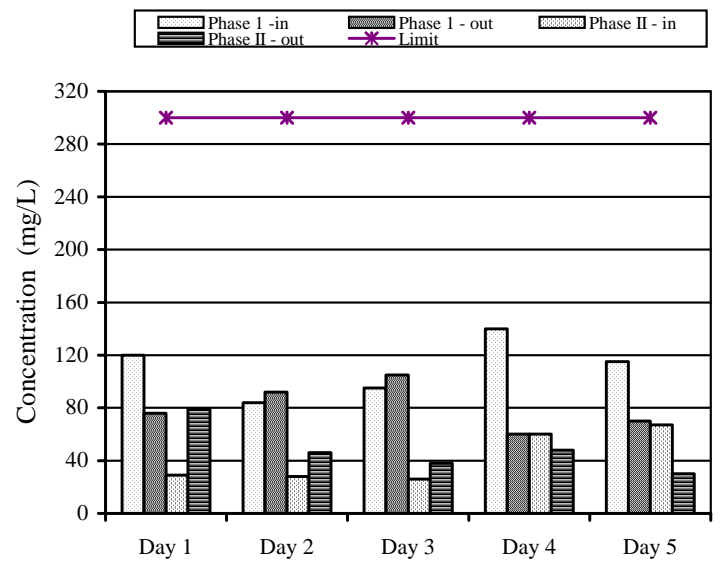

Figure 21

Concentrations of sulphates $(\mathrm{mg} / \mathrm{\ell})$ in the effluents in and out of the treatment plant on different days for Plant B, Phases I and II

of the supernatant overflow and solids rich underflow streams from these tanks. The flow of effluent into these tanks that were adjacent to each other was at rates above their designed capacities. Moreover, they were housed in the same underground structure. It was 
DPhase 1 - in $\mathbb{\$}$ Phase 1 - out $⿴ 囗 十$ Phase II - in 目Phase II - out

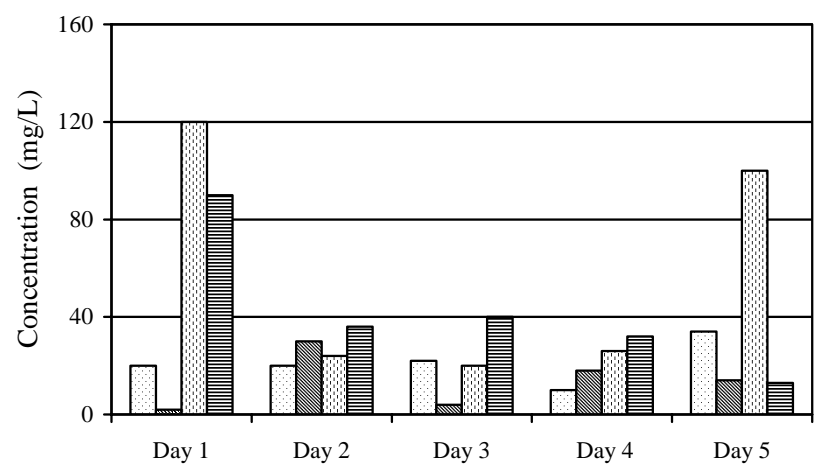

Figure 22

Concentrations of nitrates, $\mathrm{mg} / \mathrm{l}$ in the effluents in and out of the treatment plant on different days for Plant B, Phases I and II

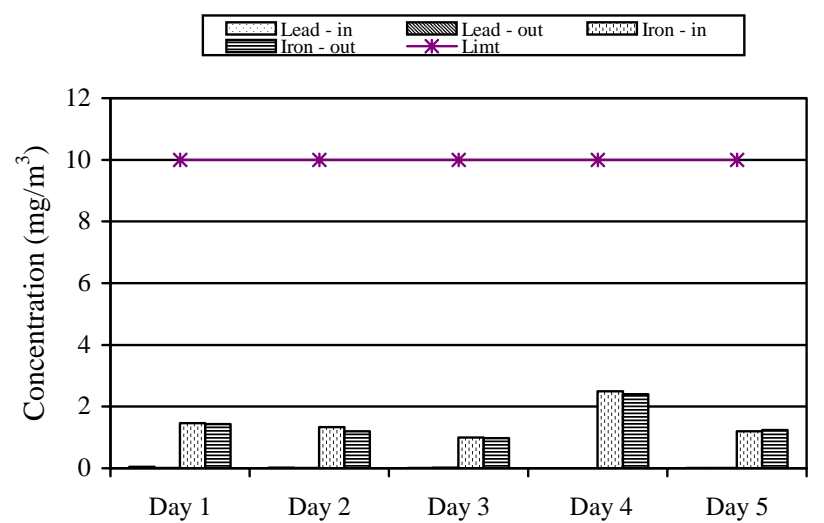

Figure 23

Concentrations of lead $(\mu \mathrm{g} / \mathrm{\ell})$ and iron $(\mathrm{mg} / \mathrm{\ell})$ in the effluents in and out of the treatment plant on different days for Plant $B$, Phase II
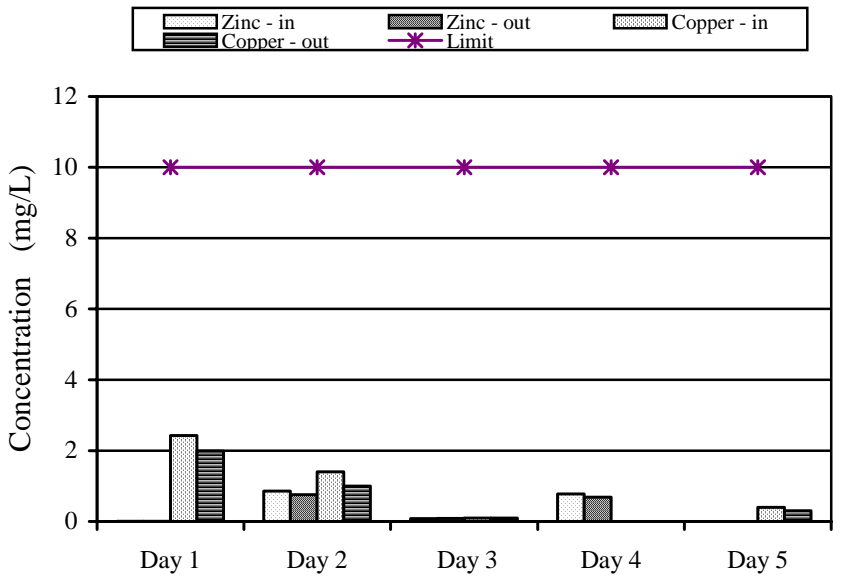

Figure 24

Concentrations of zinc ( $\mathrm{mg} / \mathrm{\ell}$ ) and copper $(\mathrm{mg} / \mathrm{l})$ in the effluents in and out of the treatment plant on different days for Plant B, Phase II

therefore not surprising to observe a re-mixing of streams of different strengths due to the overflow from one compartment to another. The main sources of TDS within the plant are from boiler blow downs and cooling tower water overflows. The inlet samples did not include effluent from boiler house and the cooling towers as these effluents were discharged directly into the equalisation tank. The sampling point was upstream of the equalisation tank.

In Plant B, the BOD values (mean $<500 \mathrm{mg} / \ell$ ) are much lower than those (mean $>900 \mathrm{mg} / \ell$ ) obtained in Plant A. There is a slight reduction in the $\mathrm{BOD}$ levels for inlet samples when compared to values for the outlet samples. This is thought to be due to possible anaerobic digestion in the equalisation tank due to irregular solids removal from the tank. The COD: BOD ratios, an average of 9.86 are higher than the range for aerobic digestion. Though the $\mathrm{K}_{\mathrm{L}}$ values of $0.15 / \mathrm{d}$ suggest that this effluent is biodegradable, it is more amenable to anaerobic digestion. Furthermore, for a brewery effluent with a BOD greater than $800 \mathrm{mg} / \ell$, anaerobic digestion is most suitable (Dupont et al., 2000).

\section{Pollution loads}

The pollution load data for Plant B(Table 4) indicate that the effluent flow rates and pollution indicators are much lower compared to Plant A values. This is due to the fact that the production capacity of Plant A is four times higher than that of Plant B. On this basis it can be suggested that Plant B is more water-efficient than Plant A. This plant would require an upgraded and larger effluent treatment unit if it is to discharge effluents that will comply with legislative requirements. The current setup is inadequate in both size and performance. However, in the meantime, planned and preventive maintenance would help to reduce equipment failure rates especially the pumps and strainer which were observed not be in operation on several occasions. The use of lime or polymeric coagulants and flocculants in the equalisation tank would bring the $\mathrm{pH}$ to within acceptable limits as well as enhancing the settling of solids in the tank. The charcoal used in the absorber should be regenerated or replaced regularly.

\section{Conclusions}

The effluents from these plants are high in COD, BOD and SS, thereby failing to comply with the required regulatory standards. An analysis of the COD: BOD ratios indicates that the effluents are biodegradable and that these effluents are amenable to anaerobic digestion. No substantial levels of heavy metals were detected as expected, these being food-related industries. Though both plants had effluent treatment plants, they were observed to be ineffective due to poor operational practices and under-design as they were no longer capable of handling the quantities of effluents presently being generated. Simple good housekeeping practices, operational adjustments and design modifications as suggested could contribute to reducing the very high pollution levels of the effluents from these plants.

\section{Acknowledgements}

The authors are grateful to SAREC/SIDA of Sweden for their financial support in carrying out this project.

\section{Disclaimer}

No information or data contained in this paper may be used for any legal purposes.

\section{References}

BULAWAYO (SEWERAGE, DRAINAGE AND WATER) BY-LAWS (1980) Section 8. 
TABLE3

Statistical summary of results for Plant B

\begin{tabular}{|c|c|c|c|c|c|c|}
\hline \multirow[t]{2}{*}{ Parameter } & \multicolumn{3}{|c|}{ Phase I } & \multicolumn{3}{|c|}{ Phase II } \\
\hline & Range & Average & $\begin{array}{l}\text { Standard } \\
\text { deviation }\end{array}$ & Range & Average & $\begin{array}{l}\text { Standard } \\
\text { deviation }\end{array}$ \\
\hline $\begin{array}{l}\mathrm{pH} \\
\text { (pH units) }\end{array}$ & $\begin{array}{l}5.9-8.9 \\
5.1-6.9\end{array}$ & $\begin{array}{l}7.0 \\
6.0\end{array}$ & $\begin{array}{l} \pm 1 \\
\pm 1\end{array}$ & $\begin{array}{l}5.9-6.7 \\
4.5-6.4\end{array}$ & $\begin{array}{l}6.2 \\
5.4\end{array}$ & $\begin{array}{l} \pm 0.3 \\
\pm 0.6\end{array}$ \\
\hline $\begin{array}{l}\text { Temperature } \\
\left({ }^{0} \mathrm{C}\right)\end{array}$ & $\begin{array}{l}21-37 \\
25-29\end{array}$ & $\begin{array}{l}31 \\
27\end{array}$ & $\begin{array}{l} \pm 5 \\
\pm 1\end{array}$ & $\begin{array}{l}23-44 \\
13-29\end{array}$ & $\begin{array}{l}31 \\
22\end{array}$ & $\begin{array}{l} \pm 9 \\
\pm 5\end{array}$ \\
\hline Phosphate & $\begin{array}{c}10-81 \\
42-164\end{array}$ & $\begin{array}{l}51 \\
82\end{array}$ & $\begin{array}{l} \pm 26 \\
\pm 42\end{array}$ & $\begin{array}{c}26-67 \\
30-101\end{array}$ & $\begin{array}{l}45 \\
55\end{array}$ & $\begin{array}{l} \pm 16 \\
\pm 22\end{array}$ \\
\hline Sulphate & $\begin{array}{l}84-140 \\
60-105\end{array}$ & $\begin{array}{c}110 \\
81\end{array}$ & $\begin{array}{l} \pm 22 \\
\pm 16\end{array}$ & $\begin{array}{l}10-84 \\
15-126\end{array}$ & $\begin{array}{l}55 \\
55\end{array}$ & $\begin{array}{l} \pm 27 \\
\pm 32\end{array}$ \\
\hline Nitrate & $\begin{array}{c}20-34 \\
2-18\end{array}$ & $\begin{array}{l}24 \\
14\end{array}$ & $\begin{array}{c} \pm 6 \\
\pm 10\end{array}$ & $\begin{array}{l}20-120 \\
10-108\end{array}$ & $\begin{array}{l}61 \\
48\end{array}$ & $\begin{array}{l} \pm 37 \\
\pm 34\end{array}$ \\
\hline COD & $\begin{array}{c}840-8340 \\
1260-12580\end{array}$ & $\begin{array}{l}4820 \\
5880\end{array}$ & $\begin{array}{l} \pm 2714 \\
\pm 3913\end{array}$ & $\left|\begin{array}{c}280-7600 \\
2620-11200\end{array}\right|$ & $\begin{array}{l}4391 \\
6650\end{array}$ & $\begin{array}{l} \pm 2422 \\
\pm 2700\end{array}$ \\
\hline BOD & $\begin{array}{l}380-2004 \\
190-1240\end{array}$ & $\begin{array}{c}1147 \\
253\end{array}$ & $\begin{array}{l} \pm 800 \\
\pm 476\end{array}$ & $\begin{array}{c}18-1072 \\
181-1000\end{array}$ & $\begin{array}{l}444 \\
466\end{array}$ & $\begin{array}{l} \pm 438 \\
\pm 340\end{array}$ \\
\hline SS & $\begin{array}{l}400-1300 \\
320-3220\end{array}$ & $\begin{array}{c}864 \\
1836\end{array}$ & $\begin{array}{c} \pm 390 \\
\pm 1185\end{array}$ & $\begin{array}{c}119-12000 \\
280-260\end{array}$ & $\begin{array}{l}614 \\
952\end{array}$ & $\begin{array}{l} \pm 381 \\
\pm 725\end{array}$ \\
\hline $\begin{array}{l}\text { Turbidity } \\
\text { (FAU) }\end{array}$ & $\begin{array}{l}640-2380 \\
480-4500\end{array}$ & $\begin{array}{l}1408 \\
2516\end{array}$ & $\begin{array}{l} \pm 6893 \\
\pm 152\end{array}$ & $\begin{array}{c}50-1470 \\
357-2740\end{array}$ & $\begin{array}{c}887 \\
1184\end{array}$ & $\begin{array}{l} \pm 496 \\
\pm 822\end{array}$ \\
\hline TDS & $\begin{array}{c}561-858 \\
737-1162\end{array}$ & $\begin{array}{l}768 \\
909\end{array}$ & $\begin{array}{l} \pm 108 \\
\pm 159\end{array}$ & $\begin{array}{c}6-6110 \\
17-7660\end{array}$ & $\begin{array}{c}926 \\
1088\end{array}$ & $\begin{array}{l} \pm 1963 \\
\pm 2331\end{array}$ \\
\hline $\begin{array}{l}\text { Conductivity } \\
(\mu \mathrm{S} / \mathrm{cm})\end{array}$ & $\begin{array}{c}1121-1719 \\
579-3120\end{array}$ & $\begin{array}{l}1531 \\
1776\end{array}$ & $\begin{array}{l} \pm 214 \\
\pm 825\end{array}$ & $\begin{array}{l}12-12210 \\
66-15310\end{array}$ & $\begin{array}{l}1851 \\
2173\end{array}$ & $\begin{array}{l} \pm 3923 \\
\pm 4659\end{array}$ \\
\hline
\end{tabular}

NOTE : All parameters are in $\mathrm{mg} / \ell$ unless otherwise stated First row data refers to raw/untreated effluent Second row data refers to treated effluent discharged from treatment plant.

\begin{tabular}{|l|c|c|}
\hline \multicolumn{3}{|c|}{ TABLE4 } \\
Pollution Load, Plant B \\
\hline Parameter & Average & Range \\
\hline Volume (m $\left.{ }^{3} / \mathrm{d}\right)$ & 168 & $60-363$ \\
COD $(\mathrm{kg} / \mathrm{d})$ & 782 & $13-3027$ \\
BOD $(\mathrm{kg} / \mathrm{d})$ & 193 & $22-726$ \\
SS $(\mathrm{kg} / \mathrm{d})$ & 142 & $0.4-2218$ \\
TDS $(\mathrm{kg} / \mathrm{d})$ & 124 & $7-472$ \\
\hline
\end{tabular}

DUPONT RR, THEODORE L and GANESAN K (2000) Pollution Prevention: The Waste Management Approach for the $21^{\text {st }}$ Century. Lewis Publishers. 187-250.

FATOKI OS and MATHABATHA S (2001) An assessment of heavy metal pollution in the East London and Port Elizabeth harbours. Water SA 27 (2) 233-240.
GRAY NF (1999) Water Technology: An Introduction for Environmental Scientists and Engineers. Arnold Publishers, Great Britain. 102-168.

HOSANG YI, JAEHONG KIM, HOO HYUNG, SANGHO LEE and CHUNG-HAK LEE (2001) Cleaner production optimisation in a food (Kimchi) industry. J. Clean. Prod. 9 (1) 36-41. Elsevier Science.

IKHU-OMOREGBE DIO, KUIPA P and NYONI V (2001) Industrial liquid effluent monitoring and disposal in Bulawayo - A review. Proc. $6^{\text {th }}$ World Congress of Chem. Eng. Melbourne, Australia.

KILANI JS and OTIENO FO (1991) Pollution effects of brewery wastes: Ruaraka River. Proc. 17th WEDC Conf. on Infrastructure, Environment, Water and People. Nairobi, Kenya.

KILANI JS (1993) A compatibility study of the effects of dairy and brewery effluents on the treatability of domestic sewage. Water SA 19 (3) 247-252.

MARSHAL BE (1997) Lake Chivero after forty years: The impact of eutrophication. In: Moyo NAG (ed.) Lake Chivero a Polluted Lake. University of Zimbabwe Publications. 1-12. 
MIHELCIC JR (1999) Fundamentals of Environmental Engineering. John Wiley and Sons. 210-270.

NORPLAN AS, STEWART SCOTT ZIMBABWE, CNM \& PARTNERS (2001) Study on the Impacts of Industrial Effluents on Sewers and Sewerage Treatment, Bulawayo Water Conservation and Sector Services Upgrading Project Industrial Effluent Report. $1-28$.

NYONI VS (1999) Some Proposed aspects of water quality management in Bulawayo in the New Millennium. Workshop Proc. on Water Quality and Conservation. Kadoma, Zimbabwe.

SKONG DA and LEARY JJ (1992) Principles of Instrumental Analysis. Saunders, New York.

STANDARD METHODS (1998) Standard Methods for the Examination of Water and Wastewater (20 $0^{\text {th }}$ edn.) APHA/AWWA/WEF Washington DC, USA.
STEPHENSON RL and BLACKBURN JB Jr (1998) Industrial Wastewater Systems Handbook. Lewis Publishers, USA 1998. 121-237.

STRYDOM JP, MOSTERT JF and BRITZ TJ (1993) effluent production and disposal in the South African dairy industry. A postal survey. Water SA 19 (3) 253-258.

SWEENEY JM (1995) Environmental information; issues and sources of urban pollution. Information Workshop, Nairobi, Kenya.

THE CHRONICLE (February 10, 2000) Mining dump washed into Bulawayo dam. Article in a daily newspaper published in Bulawayo, Zimbabwe.

WATER RESEARCH COMMISSION (1989) Water and Wastewater Management in the Sorghum Malt and Beer Industry (1989). WRC Report No TT 39/89, Pretoria. 1-31.

ZIMBABWE WATER AUTHORITY (1999) Waste Discharge and Disposal (water Pollution) Regulations, Republic of Zimbabwe. 